\title{
Pengembangan Modul Berbasis Inkuiri Terbimbing Bermuatan Artikel Ilmiah Populer Pada Materi Sistem Saraf Kelas XI
}

\author{
Rima Isnaini*, Ayatussa'adah
}

\begin{abstract}
Program Studi Tadris Biologi, Jurusan Pendidikan Matematika dan Ilmu Pengetahuan Alam, Fakulltas
Tarbiyah dan Ilmu Keguruan, IAIN Palangka Raya, Palangka Raya, Kalimantan Tengah, Indonesia

Email: isnainirima98@gmail.com
\end{abstract}

\begin{abstract}
Abstrak
Tujuan dari penelitian ini yaitu untuk mengetahui deskripsi, validitas dan kepraktisan modul berbasis inkuiri terbimbing bermuatan artikel ilmiah populer pada materi sistem saraf. Jenis penelitian ini adalah Research and Development (R\&D) dengan model pengembangan ADDIE yang terdiri dari 5 tahapan pengembangan yaitu Analysis, Design, Development, Implementation dan Evaluation. Uji produk yaitu pada skala kecil di MA Darul Ulum Palangka Raya dan instrumen yang digunakan berupa angket validasi ahli materi dan ahli media untuk mengukur validitas serta angket respon peserta didik dan angket observasi keterlaksanaan untuk mengukur kepraktisan.Hasil penelitian menunjukkan bahwa deskripsi modul yang dikembangkan yaitu berupa modul yang basis didalamnya memuat tahapantahapan inkuiri terbimbing dan merupakan modul yang memenuhi aspek materi dan media serta sesuai dengan tahap pengembangan ADDIE. Modul yang dikembangkan memperoleh nilai validasi ahli materi persentase $87 \%$ dengan kriteria valid dan validasi ahli media memperoleh persentase $75 \%$ dengan kriteria cukup valid dan dapat digunakan pada tahap selanjutnya. Sedangkan nilai kepraktisan memperoleh persentase $82 \%$ dengan kriteria sangat baik dan keterlaksanaannya memperoleh persentase 97,22\% dengan kriteria sangat berhasil. Berdasarkan hasil penelitian maka produk modul berbasis inkuiri terbimbing bermuatan artikel ilmiah populer pada materi sistem saraf dinyatakan valid dan praktis pada uji skala kecil di MA Darul Ulum Palangka Raya.
\end{abstract}

Kata Kunci : Modul, Inkuiri Terbimbing, Artikel Ilmiah Populer, Sistem Saraf

\begin{abstract}
The purpose of this study is to find out the description, validity and practicality of guided inquiry-based modules containing popular scientific articles on nervous system. This type of research is Research and Development (R\&D) with ADDIE development model consisting of 5 stages of development, namely Analysis, Design, Development, Implementation and Evaluation. Product testing is on a small scale at MA Darul Ulum Palangka Raya and the instrument used is a questionnaire validation of material experts and media experts to measure the validity and questionnaire responses of students and observations of the implementation to measure practicality. The results showed that the description of the module developed was in the form of a module whose base contained the stages of guided inquiry and was a module that met the material and media aspects and was in accordance with the ADDIE development stage. The module that was developed gained $87 \%$ material expert validation value with valid criteria and media expert validation obtained $75 \%$ percentage with sufficiently valid criteria and can be used at a later stage. While the practicality score obtained a percentage of $82 \%$ with very good criteria and the feasibility obtained a percentage of $97.22 \%$ with very successful criteria. Based on the results of the study, the guided inquiry-based module product containing popular scientific articles on the nervous system material was declared valid and practical on a small scale test at MA Darul Ulum Palangka Raya
\end{abstract}

Keywords: Guided Inquiry, Modules, Nervous System, Popular Scientific Articles. 


\section{PENDAHULUAN}

Berkembangnya ilmu pengetahuan dan teknologi mempengaruhi bidang keilmuan lain untuk berkembang, tidak terkecuali pada bidang ilmu pendidikan. Perkembangan dalam ilmu pendidikan dapat ditinjau dari beberapa aspek, antara lain kualitas pendidik, kurikulum yang digunakan, proses pembelajaran yang diterapkan, sarana dan prasarana pembelajaran, bahan ajar, metode serta media pembelajaran dan lain-lain. Perubahanperubahan tersebut bertujuan agar peserta didik mampu menguasai materi yang diajarkan secara optimal. Sebagai dampaknya adalah para pendidik harus memperkaya sumber dan media pembelajaran antara lain buku teks, modul, video, slide, hypertext, animasi, web, dan sebagainya (Setyowati, 2013). Pada proses pembelajaran, perangkat pembelajaran yang lengkap dan inovatif harus disusun oleh guru, salah satunya adalah bahan ajar yang menarik, sehingga dapat membantu guru mencapai tujuan pembelajaran. Kemudian materi yang disusun juga harus disesuaikan dengan tuntutan kurikulum dan kebutuhan peserta didik dan perlu adanya pengembangan agar dapat meningkatkan kualitas belajar peserta didik. Bahan ajar yang digunakan guru bisa dalam bentuk tulisan maupun non tulisan, salah satu contoh bahan ajar tertulis adalah modul (Lewar, 2019).

Modul merupakan jenis bahan ajar cetak yang dibuat secara terstruktur berdasarkan kurikulum yang berisi satu materi atau satu submateri dengan menggunakan bahasa yang mudah dimengerti oleh peserta didik sesuai tingkat pengetahuan yang dapat digunakan untuk belajar secara mandiri dengan bimbingan dari guru (Oktaria, 2016). Selain itu, modul juga merupakan salah satu pilihan bahan belajar mandiri, yang mana media cetak ini disusun secara sistematis yang mementingkan aktifitas belajar peserta didik, dengan tampilannya yang menarik, serta disampaikan dengan bahasa yang mudah dipahami sehingga proses pembelajaran dapat dilakukan sesuai dengan tingkat pengetahuan dan pemahaman serta dapat dilakukan di luar kelas (Setyowati, 2013).

Modul yang menarik adalah modul yang memperhatikan aspek kemenarikan isinya agar dapat menarik minat peserta didik untuk membacanya (Ginanjar, 2010). Untuk menarik minat, pada modul yang ingin dikembangkan oleh peneliti dimasukkan artikel ilmiah populer karena artikel merupkan hasil temuan ilmiah yang terbaru dan sesuai pula dengan materi yang dibahas pada materi sistem saraf. Artikel ilmiah populer ini di dalam modulnya dijadikan sebagai bagian orientasi materi yang menggunakan sintak-sintak inkuiri terbimbing untuk dasar proses perumusan masalah dan pengajuan hipotesis oleh peserta didik. Alasan lain peneliti memasukkan artikel ilmiah populer dalam modul inkuiri terbimbing ini adalah sebagai bahan orientasi sebelum masuk ke materi dan untuk mengoptimalkan pemanfaatan informasi dari hasil riset penelitian sains serta memperkaya informasi dan pengetahuan peserta didik yang berkaitan langsung dengan materi yang dipelajari yang merupakan bentuk inovasi terbaru dalam 
pembelajaran. Modul ini tentunya sangat diperlukan bagi peserta didik untuk membantu aspek kognitif dan untuk memantapkan pemahaman konsep peserta didik terkait dengan materi yang dipelajari melalui model inkuiri terbimbing yang digunakan dan juga melalui artikel ilmiah populer yang dimasukkan di dalamnya juga dapat memfasilitasi peserta didik belajar secara optimal dan sekaligus dapat memperkaya informasi terkait materi yang dibahas.

Hasil observasi dan wawancara langsung dengan guru mata pelajaran Biologi MA Darul Ulum Palangka Raya diperoleh data bahwa pada kegiatan pembelajaran di kelas peserta didik hanya menggunakan LKPD (Lembar Kerja Peserta Didik) sebagai bahan ajar. Tidak ada buku referensi pembelajaran yang lain yang dapat menunjang pembelajaran terlebih pada kesehariannya peserta didik tidak diperkenankan membawa alat elektronik (handphone) yang dapat digunakan untuk mengakses ilmu lebih luas dan untuk mencari referensi untuk memperdalam materi yang sedang dipelajari. Selain itu sarana yang ada di sekolah belum bisa mendukung secara penuh kegiatan pembelajaran seperti perpustakaan yang tidak memadai karena tidak menyediakan buku-buku pembelajaran lain seperti buku teks, modul, ensiklopedia dan lain sebagainya yang dapat memfasilitasi peserta didik untuk memproleh ilmu lebih banyak dan mendalami materi yang sedang dipelajari.

Guru pengampu mata pelajaran biologi juga mengatakan bahwa peserta didik masih kesulitan dalam beberapa materi pelajaran biologi khususnya pada materi sistem saraf yang mana materi ini dianggap materi yang sulit karena bersifat abstrak bagi peserta didik sehingga peserta didik mengalami kesulitan dalam memahami konsep dan berimbas pada nilai peserta didik. Menurut Saragih (2016) Materi sistem saraf merupakan salah satu materi biologi yang tergolong rumit, karena mempelajari bagian-bagian dan struktur saraf yang sulit dilihat tanpa alat bantu serta banyak terdapat istilah asing sehingga sulit dipahami oleh peserta didik. Selain itu, menurut Purwanti (2011) mengemukakan bahwa konsep sistem saraf merupakan materi yang sebagian besar bersifat abstrak sehingga akan sulit dipahami apabila hanya menggunakan metode ceramah dan diskusi. Berdasarkan hasil wawancara guru Biologi di MA Darul Ulum Palangka Raya ketika mengajar di kelas biasa menggunakan metode ceramah dan diskusi, ternyata hasilnya masih banyak peserta didik yang belum dapat memahami materi yang dipelajari karena kecepatan pemahaman yang berbeda-beda diantara setiap peserta didik sehingga perlu dilaksanakannya pembelajaran lain yang lebih bervariasi dan salah satu variasi pembelajaran yang bisa dilakukan adalah melalui model yang digunakan oleh guru yaitu salah satunya dengan menggunakan model inkuiri terbimbing.

Menurut Oktaria (2016) Biologi yang merupakan bagian dari Ilmu Pengetahuan Alam memang berkaitan dengan cara mencari tahu (inquiry) tentang alam secara sistematis, sehingga bukan hanya penguasaan kumpulan 
pengetahuan yang berupa fakta-fakta, konsepkonsep atau prinsip-prinsip saja, tetapi juga merupakan suatu proses penemuan. Mengembangkan pengetahuan peserta didik dapat dilakukan dengan cara menemukan (inquiry) untuk mengetahui ide-ide suatu permasalahan.

Model pembelajaran inkuiri terbimbing adalah salah satu model pembelajaran yang berpusat pada peserta didik dimana peserta didik dituntut aktif dalam melakukan pembelajaran dengan bimbingan guru, namun terdapat beberapa kendala dalam penerapan inkuiri terbimbing pada proses pembelajaran. Tetapi kendala tersebut dapat diatasi dengan melakukan pembelajaran secara mandiri oleh peserta didik dengan menerapkan kemampuan inkuiri menggunakan media pembelajaran yang tepat, yaitu modul (Kristin, 2016).

Berdasarkan analisis masalah dan studi penelitian terkait maka tujuan dari penelitian ini adalah untuk mengetahui deskripsi, validitas dan kepraktisan modul berbasis inkuiri terbimbing bermuatan artikel ilmiah populer pada materi sistem saraf.

\section{METODE PENELITIAN}

Penelitian ini adalah Research and Development (R\&D) dengan model pengembangan ADDIE yang terdiri dari 5 tahapan pengembangan yaitu Analysis, Design, Development, Implementation dan Evaluation (Asim, 2001). Uji produk yaitu pada skala kecil di MA Darul Ulum Palangka Raya dan instrumen yang digunakan berupa angket validasi ahli materi dan ahli media untuk mengukur validitas serta angket respon peserta didik dan angket observasi keterlaksanaan untuk mengukur kepraktisan. Data yang diperoleh dalam penelitian ini dianalisis secara kuantitatif untuk kemudian dianalisis secara kualitatif deskriptif.

\section{HASIL DAN PEMBAHASAN}

a. Deskripsi Modul

Deskripsi modul berbasis inkuiri terbimbing bermuatan artikel ilmiah populer pada materi sistem saraf yaitu berupa modul cetak yang didalamnya memuat tahapan-tahapan inkuiri terbimbing dan merupakan modul yang telah memenuhi aspek materi dan media/desain.

Deskripsi modul berbasis inkuiri terbimbing bermuatan artikel ilmiah populer pada materi sistem saraf yang dikembangkan yaitu sebagai berikut:

1) Identitas produk

Bentuk : Bahan cetak (Material printed)

Judul : Modul Berbasis Inkuiri Terbimbing Bermuatan Artikel Ilmiah Populer pada Materi Sistem Saraf Kelas XI MA Darul Ulum Palangka Raya

Sasaran : Peserta didik kelas XI MA Darul Ulum Palangka Raya

Nama $\quad$ : Rima Isnaini

Pembuat 
Cetakan : Pertama

Ukuran : A4

2) Wujud fisik dari produk yang dihasilkan dalam pengembangan ini adalah berupa media cetak berupa modul (material printed).

3) Modul ini dikembangkan dengan basis pengembangannya adalah dengan menggunakan model inkuiri terbimbing yang merupakan model pembelajaran penemuan atau mencari yang mana peserta didik dibimbing secara hati-hati untuk menemukan jawaban terhadap masalah yang dihadapkan kepada peserta didik untuk diselesaikan baik melalui diskusi kelompok maupun secara individu agar mampu menyelesaikan masalah dan menarik suatu kesimpulan secara mandiri. Pada modul yang dikembangan ini tahapan-tahapan inkuiri terbimbing turut menjadi penuntun dalam proses belajar dalam modul sehingga menjadi ciri khas produk modul yang dikembangkan.

4) Hasil belajar yang sesuai dengan pembelajaran dengan menggunakan modul yang dikembangkan ini ditujukan untuk mencapai KI, KD yang ada dalam kurikulum 2013.

5) Bentuk fisik modul dalam pengembangan ini berupa media cetak yang disusun dengan menggunakan variasi tata letak, pilihan warna, variasi huruf sehingga modul ini menjadi menarik untuk dijadikan bahan ajar.

6) Produk berupa modul ini merupakan hasil analisis pengembangan dari dua aspek yaitu aspek materi dan aspek media (design). Aspek materi meliputi Cover, kata pengantar, petunjuk penggunaan modul, kompetensi inti dan kompetensi dasar, daftar isi, peta konsep, kegiatan belajar, rangkuman, uji kompetensi, umpan balik, glosarium, daftar pustaka, indeks, kunci jawaban dan biografi. Sedangkan aspek media atau desain meliputi ukuran halaman, tipe font, ukuran font, warna modul, spasi dan gambar/ilustrasi.

\section{b. Validasi Modul}

Modul pembelajaran dinyatakan valid oleh ahli materi dengan persentase total penilaian $87 \%$ dan dinyatakan valid oleh ahli media/design dengan persentase total penilaian $75 \%$. Tabel penilaian hasil validasi modul adalah sebagai berikut:

1) Hasil Validasi Ahli Materi

Materi dalam produk ini dinilai oleh 2 orang ahli materi yang berstatus sebagai Dosen di Prodi Tadris Biologi IAIN Palangka Raya yaitu Abu Yazid Nukti M.Pd dan Ridha Nirmalasari, S.Si.M.Kes. Adapun data hasil validasi materi dapat dilihat pada Tabel 1.

Tabel 1. Hasil Validasi Ahli Materi

Keterangan: (80-100\% Valid/tidak

\begin{tabular}{lcccc}
\hline Aspek yang dinilai & $\begin{array}{c}\text { Skor } \\
\text { Total }\end{array}$ & $\begin{array}{c}\text { Skor } \\
\text { Maks }\end{array}$ & $\begin{array}{c}\text { Persen- } \\
\text { tase }\end{array}$ & $\begin{array}{c}\text { Krite- } \\
\text { ria }\end{array}$ \\
\hline $\begin{array}{l}\text { Keakuratan Materi, } \\
\text { Pendukung }\end{array}$ & 273 & 312 & $87 \%$ & $\begin{array}{c}\text { Sanga } \\
\text { t Baik }\end{array}$ \\
$\begin{array}{l}\text { Penyajian, } \\
\text { Kesesuaian dengan }\end{array}$ & & & & \\
Inkuiri Terbimbing, & & & &
\end{tabular}


revisi), (60-79\% cukup valid/tidak revisi), (40-59\% kurang valid/revisi sebagian), (0-39\% Tidak valid/revisi) (Arikunto, 2003)

Berdasarkan Tabel 1 dapat diketahui bahwa proses validasi bagian materi dinyatakan masuk dalam kriteria valid dan dapat diujicobakan dalam skala kecil.

2) Hasil Validasi Ahli Media (Desain)

Desain dalam produk ini dinilai oleh 2 orang ahli media yaitu Dosen Mata Kuliah Teknologi Informasi Usmiyatun M.Pd. dan Dosen mata kuliah Pengembangan Modul Susilawati M.Pd. di IAIN Palangka Raya. Adapun hasil validasi ahli materi dapat dilihat pada Tabel 2 .

Tabel 2. Hasil Validasi Ahli Media

\begin{tabular}{lcccr}
\hline $\begin{array}{c}\text { Aspek yang } \\
\text { dinilai }\end{array}$ & $\begin{array}{c}\text { Skor } \\
\text { Total }\end{array}$ & $\begin{array}{c}\text { Skor } \\
\text { Maks }\end{array}$ & $\begin{array}{c}\text { Persen- } \\
\text { tase }\end{array}$ & Kriteria \\
\hline $\begin{array}{c}\text { Ukuran Modul, } \\
\text { Desain Sampul }\end{array}$ & 78 & 104 & $75 \%$ & Baik \\
Modul, Desain \\
Modul
\end{tabular}

\section{c. Kepraktisan Modul}

Modul juga dinyatakan valid berdasarkan respon dari peserta didik dan observer yang turut mengamati jalannya pembelajaran menggunakan modul yang dikembangkan. Hasil penilaian kepraktisan dari dapat dilihat pada tabel 3 dan 4 berikut:

1) Respon Peserta Didik

Produk pengembangan ini diuji cobakan pada skala kecil yaitu kepada 5 orang peserta didik kelas XI MA Darul Ulum Palangka Raya dengan memberikan angket respon yang berfungsi untuk mengetahui kelayakan modul yang dikembangkan. Hasil respon peserta didik di uji skala kecil memperoleh persentase total $82 \%$ dengan kriteria "sangat praktis." Berikut adalah hasil respon peserta didik pada skala kecil dapat dilihat pada Tabel 3.

Tabel 3. Tabel Hasil Penilaian Uji

Coba Skala Kecil

\begin{tabular}{|c|c|c|c|c|}
\hline No & Responden & Jumlah & Persentase & Kriteria \\
\hline 1 & BS & 81 & $81 \%$ & $\begin{array}{c}\text { Sangat } \\
\text { Baik }\end{array}$ \\
\hline 2 & $\mathrm{FE}$ & 89 & $89 \%$ & $\begin{array}{c}\text { Sangat } \\
\text { Baik }\end{array}$ \\
\hline 3 & NY & 83 & $83 \%$ & $\begin{array}{c}\text { Sangat } \\
\text { Baik }\end{array}$ \\
\hline 4 & SY & 93 & $93 \%$ & $\begin{array}{c}\text { Sangat } \\
\text { Baik }\end{array}$ \\
\hline 5 & $\mathrm{TN}$ & 64 & $64 \%$ & $\begin{array}{l}\text { Cukup } \\
\text { Baik }\end{array}$ \\
\hline
\end{tabular}

Berdasarkan hasil analisis data pada tabel 3 diketahui bahwa modul berbasis inkuiri terbimbing bermuatan 
artikel ilmiah populer yang dikembangkan secara umum sudah baik untuk digunakan sebagai bahan ajar. Hal ini ditunjukkan dari persentase yang diperoleh dari hasil penilaian skala kecil. Skor rata-rata persen adalah sebesar 82\%, maka produk modul yang dikembangkan tidak perlu revisi karena semua item yang dinilai sangat menarik.

\section{2) Penilaian Observer}

Keterlaksanaan model pembelajaran dalam modul di penelitian online ini diamati oleh observer. Adapun observer dalam penelitian ini berjumlah 2 orang, yaitu Maharani Nida Ervina Mahasiswi IAIN Palangka Raya dan Salas Tino Mahasiswa Universitas Antakusuma Pangkalan Bun, observer 1 mengamati 2 orang peserta didik dan observer 2 mengamati 3 orang peserta didik dalam skala kecil selama pembelajaran berlangsung. Penilaian observer dapat dilihat pada Tabel 4 berikut.

Tabel 4. Keterlaksanaan Model Pembelajaran Dalam Modul

\begin{tabular}{ccc}
\hline & \multicolumn{2}{c}{ Observer } \\
\cline { 2 - 3 } Rata-Rata & \multicolumn{2}{c}{2} \\
\cline { 2 - 3 } Skor & \multicolumn{2}{c}{87,50} \\
Persentase & \multicolumn{2}{c}{$97,22 \%$} \\
Skor & \\
Kriteria & \multicolumn{2}{c}{ Sangat Berhasil } \\
\hline
\end{tabular}

Berdasarkan keterangan pada Tabel 4 diatas, keterterapan model pembelajaran inkuiri terbimbing dalam modul memperoleh persentase skor 97,22\% dengan kriteria sangat berhasil, sehingga modul dapat dikatakan layak untuk digunakan dalam pembelajaran materi sistem saraf.

Modul yang dikembangkan ini telah melalui beberapa tahapan validasi oleh para pakar ahli baik itu ahli materi maupun ahli media. Produk yang dikembangkan berupa modul ini terdiri dari sampul, kata pengantar, petunjuk penggunaan modul, kompetensi inti dan kompetensi dasar, daftar isi, peta konsep, kegiatan belajar, tahapan inkuiri terbimbing, rangkuman, uji kompetensi, umpan balik, glosarium, daftar pustaka, kunci jawaban dan biodata penulis/biografi (Direktorat Tenaga Kependidikan, 2008 dan Hernawan, 2013).

Modul yang dikembangkan ini adalah modul berbasis inkuiri terbimbing sehingga tahapan-tahapan inkuiri terbimbing juga termuat dalam modul yang membuat peserta didik turut memberikan respon positif terhadap pembelajaran biologi menggunakan modul berbasis inkuiri terbimbing ini karena dinilai sangat menarik tetapi karena pada penelitian ini dilakukan secara online sehingga tidak semua tahapan inkuiri terbimbing terlaksana dengan optimal sehingga menjadi kelemahan atau kekurangan dalam penelitian yang dilakukan. Menurut Oktaria (2016), modul berbasis inkuiri terbimbing menarik bagi peserta didik karena memudahkan mereka dalam memahami materi yang dipelajari dan karena berisi kegiatan yang menghadapkan 
peserta didik kepada suatu pemberian masalah dan menguji hipotesis tentang proses faktual dengan dalam kehidupan sehari-hari dengan bimbingan guru serta berisi kegiatan yang mendorong peserta didik untuk melakukan kegiatan inkuiri terbimbing yang berkaitan dengan materi yang dipelajari sehingga peserta didik memberikan respon positif terhadap pembelajaran biologi yang dilakukan dengan menggunakan modul berbasis inkuiri terbimbing.

Validitas dilakukan pada tahap pertama di proses development atau pengembangan. Validasi dinilai langsung oleh para ahli materi dan ahli media dan validasi dapat dikatakan tinggi apabila hasilnya dapat digunakan secara tepat dan dapat memberikan hasil sesuai dengan yang diharapkan. Artinya hasil yang diinginkan pada modul tersebut dapat menjadi bahan acuan dalam belajar dan meningkatkan hasil belajar peserta didik. Selain itu, modul juga dapat dikatakan valid apabila sudah melalui beberapa tahap seperti validasi oleh ahli (Ginanjar, 2010).

Menurut Sari (2017), proses validasi dapat dilakukan sebanyak 2 kali oleh masing-masing validator sesuai dengan kebutuhan penelitian untuk menyesuaikan apa yang dibutuhkan peserta didik dengan apa yang telah dikembangkan sehingga pada penelitian ini proses validasi dilakukan sebanyak 2 kali karena hanya sampai pada tahapan uji skala kecil. Proses validasi dilakukan sampai validator menyatakan bahwa modul telah layak digunakan tanpa revisi.
Dalam penelitian ini, modul dinyatakan valid karena memenuhi kriteria yang baik dari segi materi dan media (design).

Modul yang dikembangkan berdasarkan hasil penelitian yang dilakukan telah mencapai kepraktisan berdasarkan hasil respon peserta didik dengan persentase penilaian sebesar $82 \%$ dengan kriteria sangat baik dan keterlaksanaan pembelajaran dinyatakan berhasil dengan melihat penilaian dan pendapat dari 2 observer yang ikut mengamati kegiatan pembelajaran secara online di dalam grup Whatsapp yang dibuat khusus oleh peneliti untuk melaksanakan proses penelitian dengan hasil persentase penilaian sebesar 97,22\% dengan kriteria sangat berhasil. Keterlaksanaan pembelajaran modul yang dikembangkan dapat dikatakan berhasil apabila mampu mengarahkan peserta didik untuk terlibat aktif dan dapat belajar mandiri. Kepraktisan modul dapat diukur dengan melihat kegunaan dari modul yang dikembangkan oleh peserta didik. Indrawati (2009); Khayati (2015); dan Murdiyah (2015) menyatakan bahwa keterlaksanaan pembelajaran menggunakan modul terlaksana dengan baik atau masuk dalam kriteria tinggi jika peserta didik terlihat aktif dan berinteraksi dengan peserta didik lainnya maupun dengan pendidik untuk memecahkan permasalahan atau pernyataan yang berkaitan dengan materi pembelajaran. Hasil penelitian ini dinyatakan praktis 
dengan melihat tahapan-tahapan inkuiri terbimbing yang juga terlaksana dengan baik yang dapat dilihat dari antusias dan keefektifan peserta didik selama proses pembelajaran dengan menggunakan modul pembelajaran yang dikembangkan. Peserta didik memberikan respon yang sangat baik untuk menyatakan kepraktisan modul. Jadi, modul pembelajaran yang dikembangkan telah memenuhi syarat kepraktisan. Hal ini didukung oleh Ismail (2013) yang menyatakan bahwa keterlaksanaan pembelajaran yang baik adalah jika derajat keterlaksanaan pembelajaran yang dicapai tersebut minimal berkategori tinggi atau baik.

\section{SIMPULAN}

Modul pembelajaran dinyatakan valid oleh ahli materi dengan persentase total penilaian $87 \%$. Modul dinyatakan valid oleh ahli media/design dengan persentase total penilaian $75 \%$.

Modul dinyatakan praktis berdasarkan respon baik dari peserta didik dengan persentase $82 \%$ dan ditinjau dari tingkat kemudahan peserta didik dalam menggunakan modul selama proses pembelajaran Modul juga dinyatakan praktis yaitu berdasarkan penilaian keterlaksanaan pembelajaran secara online yang diamati oleh observer yakni dengan persentase $97,22 \%$ dengan kriteria sangat berhasil karena peserta didik terlihat aktif dan antusias dalam belajar.

\section{DAFTAR PUSTAKA}

Asim. 2001. Sistematika Penelitian Pengembangan. Malang: Universitas Negeri Malang

Ginanjar A. 2010. Pengembangan Media Pembelajaran Modul Interaktif Mata Kuliah Pemindahan Tanah Mekanik Doctoral dissertation. Universitas Sebelas Maret.

Indrawati R. 2009. Pembelajaran Remedi Menggunakan Modul dan Animasi pada Materi Kesetimbangan Kimia Ditinjau dari Tingkat Kesulitan Belajar Siswa. Doctoral dissertation. Universitas Sebelas Maret.

Khayati F. 2015. Pengembangan Modul Matematika Untuk Pembelajaran Berbasis Masalah (Problem Based Learning) Pada Materi Pokok Persamaan Garis Lurus Kelas VIII SMP. Doctoral dissertation. Universitas Negeri Sebelas Maret.

Lewar AK. 2019. Pengembangan Modul Berbentuk Scrap Book Materi Sistem Saraf Kelas XI SMA. Skripsi. Universitas Sanata Dharma

Murdiyah N. 2014. Penggunaan Siklus Belajar 5E untuk Meningkatkan Keterampilan Berpikir Kritis Siswa Mata Pelajaran IPA di Sekolah Dasar. Jurnal Penelitian Pendidikan Guru Sekolah Dasar, 2 (2): 1-10.

Kristin D. 2016. Pengembangan Modul Pembelajaran Berbasis Inkuiri Terbimbing pada Materi Elastisitas 
dan Hukum Hooke. Skripsi.

Pendidikan Fisika FKIP Universitas

Lambung Mangkurat.

Oktaria Y. 2016. Pengembangan Modul Biologi Berbasis Inkuiri Terbimbing pada Materi Pencemaran Lingkungan untuk Siswa Kelas X SMA. IAIN Raden Intan.

Purwanti T. 2011. Pembelajaran Sistem Saraf Dengan Teknologi Informasi Dan Tutor Sebaya Di MAN 2 Kudus. Skripsi. Jurusan Biologi FMIPA Universitas Negeri Semarang.
Saragih SW. 2016. Analisis Kognitif Dan Kesulitan Belajar Siswa Pada Materi Pokok Sistem Saraf Di Kelas XI SMA Negeri 3 Sibolga Tahun Pembelajaran 2015/2016. Skripsi. Universitas Negeri Medan.

Setyowati, WR. 2013. Pengembangan Modul Biologi Berbasis Inkuiri Terbimbing pada Materi Pokok Ekosistem Semester 2 Kelas X SMA/MA. Skripsi. Universitas Islam Negeri Sunan Kalijaga 